\title{
Analisis Proses Berpikir Kritis Siswa dalam Pemecahan Masalah Relasi dan Fungsi pada Siswa SMP
}

\author{
Imayanti $^{1}$, Syarifuddin ${ }^{2 *}$, Mikrayanti $^{2}$ \\ ${ }^{1}$ Mahasiswa Prodi Pendidikan Matematika, STKIP Bima, Kota Bima, Indonesia \\ ${ }^{2}$ Dosen Prodi Pendidikan Matematika, STKIP Bima, Kota Bima, Indonesia
}

*Coresponding Author: syarifuddin.stkipbima@gmail.com

\begin{tabular}{l}
\hline \hline Article history \\
\hline Dikirim: \\
06-11-2021
\end{tabular}

Tujuan penelitian ini yaitu untuk menganalisi bagaimana Proses Berpikir Kritis Siswa dalam Pemecahan Masalah Relasi dan Fungsi pada Siswa SMP Negeri 11 Kota Bima. Penelitian ini menggunakan

Direvisi:

09-12-2021

Diterima:

$10-12-2021$

Key words:

Berpikir Kritis;

Pemecahan Masalah;

Relasi dan Fungsi pendekatan deskriptif kualitatif. Subjek dalam penelitian ini adalah 3 Orang siswa berdasarkan tingkat kemampuan tinggi,sedang dan rendah siswa kelas VIII di SMP Negeri 11 Kota Bima dalam menyelesaikan soal yang diberikan. Instrumen dalam penelitian ini yaitu 1) Lembar tes berpikir kritis, 2) Observasi, 3) Wawancara, 4) Dokumentasi. Analisis data dalam penelitian ini yaitu 1) Reduksi Data. 2) Penyajian Data, dan 3) Pengambilan kesimpulan/verifikasi. Berdasarkan hasil penelitian ini yaitu 1. Berdasarkan hasil dari penelitian dapat disimpulkan bahwa kesalahan yang dilakukan oleh siswa dalam menyelesaikan soal materi Relasi dan Fungsi yang ditinjau dari komunikasi matematika pada tiap indikator diantaranya pada indikator menyatakan masalah sehari-hari ke dalam bahasa atau simbol atau menyususn model matematika adalah siswa salah dalam menyimbolkan data yang diketahui, salah menuliskan apa yang ditanyakan. Pada indikator melakukan dugaan siswa salah dalam menentukan rumus, salah dalam menghitung data prasyarat, siswa tidak menuliskan rumus. Kesalahan pada indikator melakukan operasi matematika yaitu kesalahan penggunaan tanda operasi matematika, siswa salah dalam memasukkan data yang diketahui dalam soal, salah dalam urutan operasi matematika. 2. Penyebab siswa melakukan kesalahan dalam menyelesaikan soal Relasi dan Fungsi yang ditinjau dari komunikasi matematika diantaranya, Siswa kesulitan dalam mengubah soal cerita ke dalam simbol matematika, siswa tidak terbiasa dalam menuliskan apa yang diketahui dan yang ditanyakan, siswa tidak ingat rumus-rumus pada materi Relasi dan Fungsi, kurangnya latihan untuk soal-soal cerita, siswa sering terburu-buru dalam mengerjakan soal dan tidak mengecek ulang jawaban, mayoritas siswa tidak belajar terlebih dahulu sebelum ulangan, anggapan siswa bahwa menuliskan apa yang diketahui dan yang ditanyakan tidak terlalu penting bahkan akan menguraningi waktu dalam perhitungan.

\section{PENDAHULUAN}

Matematika sebagai salah satu ilmu pengetahuan yang memiliki perasaan penting dalam pendidikan. Matematika juga merupakan ilmu pengetahuan yang mendasari perkembangan teknologi modern lainnya. Tidak hanya dalam teknologi dan ilmu pengetahuan lainnya, konsep matematika digunakan dalam kehidupan sehari-hari.

@ 2021 DIKSI (https://jurnal.bimaberilmu.com/index.php/diksi) 
Berdasarkan kurikulum di sekolah formal, matematika merupakan salah satu mata pelajaran wajib di sekolah. Permendiknas Nomor 22 tahun 2006, tujuan pembelajaran matematika di antaranya siswa dapat: (1) Memahami konsep matematika, menjelaskan keterkaitan antar konsep dan mengaplikasikan konsep/algoritma, secara luwes, akurat, efisien, dan tepat dalam pemecahan masalah; (2) Menggunakan penalaran pada pola dan sifat, melakukan manipulasi matematika dalam membuat generalisasi, menyusun bukti, atau menjelaskan gagasan dan pernyataan matematika; (3) Memecahkan masalah yang meliputi kemampuan memahami masalah, merancang model matematika, menyelesaikan model dan menafsirkan solusi yang diperoleh; (4) Mengkomunikasikan gagasan dengan simbol, tabel, diagram, atau media lain untuk memperjelas keadaan atau masalah; (5) Memiliki sikap menghargai kegunaan matematika dalam kehidupan, yaitu memiliki rasa ingin tahu, perhatian, dan minat dalam mempelajari matematika, serta sikap ulet dan percaya diri dalam pemecahan masalah, dapat disimpulkan bahwa matematika adalah ilmu yang mempelajari tentang logika, pola pikir, dan pola mengorganisasikan konsep-konsep yang dapat dimanfaatkan dalam memahami dan mengatasi permasalahan sosial, ekonomi, dan alam.

Sebagaimana situasi dan kondisi di Indonesia saat ini, yaitu masa pandemi virus Covid-19, menyebabkan masyarakat dilarang berkumpul dalam keramaian. Virus corona menular sangat cepat dan telah menyebar hampir semua negara, termaksud Indonesia. Dengan demikian menerapkan PSBB untuk mencegah penyebaran COVID-19. Sekolah merupakan salah satu tempat dimana siswa dan guru melakukan proses pembelajaran dalam satu kelas dan berda dalam lingkungan keramaian. Karena virus COVID-19, pemerintah mengedarkan surat edaran bahwa sekolah harus dikosongkan dan tetap melanjutkan pembelajaran dengan cara menerapkan pembelajaran daring. Sementara itu, sekarang sekolah dibolehkan untuk tatap muka pada masa pandemi ini tetapi dengan waktu pelajaran yang berubah dari yang sebelunya.

Berdasarkan hasil observasi awal dengan salah satu guru matematika di SMP Negeri 11 Kota Bima, Guru matematika menjelaskan adanya perubahan jam pelaksanaa pelajaran dari sebelumnya yang dari 45 menit/jam menjadi 20 menit/jam tentu itu membuat guru harus pintar-pintar dalam mengolah strategis dalam mengajar agar pelajaran mampu terealisasikan dengan baik. Selain itu adanya kesulitan memahami pelajaran oleh siswa dikarenakan pada proses pembelajaran daring siswa cepat lupa dengan materi yang telah diajarkan selain itu faktor adanya sebagian siswa yang tidak memiliki komputer dan smartphone sehingga menghambat proses pembelajaran secara efektif, dengan adanya kendala-kendala selama mengikuti sekolah daring, siswa ketika kembali melakukan sekolah tatap muka terdapat kelaskelas tertentu yang memiliki kondisi cukup, disebabkan karena masih banyak siswa yang mengalami kesulitan dalam memahami pelajaran yang diajarkan, terdapat beberapa siswa dalam pemecahan masalah masih sangat rendah salah satunya dalam materi relasi dan fungsi. Hal itu ditunjukkan dengan pasifnya siswa disaat pembelajaran, belum ada keberanian untuk bertanya dan mengungkapkan pendapatnya disaat pembelajaran berlangsung.

@ 2021 DIKSI (https://jurnal.bimaberilmu.com/index.php/diksi) 
Berpikir kritis adalah ketrampilan yang memiliki peranan penting pada abad ke-21. Ketrampilan berpikir kritis, telah menjadi hal penting bagi masyarakat pada era global (Basri et al., 2019). Karena semakin pesatnya pertumbuhan teknolgi informasi dan komunikasi membuat informasi yang tersedia semakin banyak. Siswa harus memiliki ketrampilan berpikir sehingga mereka dapat menganalisis dan membandingkan informasi yang beredar serta dapat membuat argument.

Berpikir kritis adalah suatu pemikiran yang masuk akal, Ennis dalam (Basri et al., 2019). Berpikir kritis didefenisikan sebagai suatu pemikiran yang terampil dan bertanggung jawab dan bergantung pada kriteria sensitif terhadap konteks, Lipman dalam (Basri et al., 2019). Maka dari itu, keterampilan berpikir kritis sangat penting sehingga perlu diajarkan kepada siswa dan dimasukan dalam kurikulum pendidikan.

Sehubungan dengan pentingnnya berpikir kritis untuk siswa beberapa ahli mengungkapkan bahwa konsep dasar pemikiran kritis yaitu kemampuan menganalisis, menafsirkan, meyimpulkan, mengevaluasi dengan jelas mendefenisikan konseptual atau kriteria terhadap penilaian-penilaian serta pengendalian diri (Facione, 2011). Konsep ini juga dipertegas oleh Paul dan Elder yang mengungkapkan berpikir kritis yaitu proses dalam meningkatkan kualitas dalam berpikir dengan tujuan memperhitungkan perubahan struktural sesuai dengan standar intelektual (Rachmantika \& Wardono, 2019).

Keberhasilan dalam belajar tidak terlepas dari faktor dalam diri (internal) dan faktor luar diri (eksternal) pada diri siswa. Aunurrahman (2012) berpendapat bahwa keberhasilan belajar seorang siswa tidak lepas dari unsur internal dan unsur eksternal yang ada pada diri seseorang tersebut. Dari unsur internal antara lain ciri khas/karakteristik siswa, sikap terhadap belajar, motivasi belajar, konsentrasi belajar, mengolah bahan belajar, menggali bahan belajar, rasa percaya diri, dan kebiasaan belajar. Sedangkan faktor eksternal meliputi: keterampilan guru, lingkungan sosial (teman sebaya), kurikulum sekolah, sarana dan prasarana. Siswono (2008) berpendapat bahwa terdapat empat faktor yang mempengaruhi kemampuan siswa dalam pemecahan masalah. Keempat faktor tersebut adalah pengalaman awal, latar belakang matematika, struktur masalah, dan motivasi. Keberadaan motivasi sangatlah diperlukan dalam proses pemecahan masalah matematika. Kemampuan siswa dalam memotivasi dirinya sendiri merupakan salah satu aspek dalam kecerdasan emosional.

\section{METODE PENELITIAN}

Penelitian ini merupakan penelitian deskriptif kualitatif. Sugiyono (2012) mengemukakan penelitian kualitatif sebagai metode penelitian yang berlandaskan pada filsafat postpositivisme, digunakan untuk meneliti pada kondisi objek alamiah, dimana peneliti adalah sebagai instrumen kunci, teknik pengumpulan data, analisis data bersifat induktif atau kualitatif, dan hasil penelitian kualitatif lebih menekankan makna dari pada generalisasi.

Penelitian deskriptif kualitatif yaitu rangkaian kegiatan untuk memperoleh data yang bersifat apa adanya tanpa ada dalam kondisi tertentu yang hasilnya lebih menekankan makna. Penelitian ini menggunakan metode penelitian deskriptif

@ 2021 DIKSI (https://jurnal.bimaberilmu.com/index.php/diksi) 
kualitatif yang bertujuan untuk mendeskripsikan Analisis Proses Berpikir Kritis Siswa dalam Pemecahan Masalah Relasi dan Fungsi Pada Siswa SMP.

Dalam penelitian kualitatif tidak ada desain secara khusus seperti penelitan kuantitatif, penelitian kualitatif didesain secara longgar, tidak ketat sehingga dalam pelaksanaa penelitian berpeluang mengalami perubahan dari apa yang direncanakan. Desain kualitatif memiliki sifat luwes, akan berkembang sejalan berkembangnya pekerjaan lapangan (Gunawan, 2013).

Spradley (Sugiyono, 2009) mengungkapkan bahwa dalam penelitian kualitatif tidak menggunakan istilah populasi, tetapi dinamakan social situation atau situasi sosial yang terdiri dari tiga elemen, yaitu tempat (place), pelaku (actors), dan aktivitas (activity) yang berinteraksi secara sinergis. Subjek dalam penelitian ini adalah 3 Orang siswa berdasarkan tingkat kemampuan tinggi, tingkat kemampuan sedang dan tingkat kemampuan rendah.

Data dalam penelitian ini berasal dari:

a. Jawaban tertulis dari siswa dalam bentuk pemecahan masalah soal materi Relasi dan Fungsi.

b. Hasil wawancara yang diperoleh dari subjek penelitian guna menggali informasi tentang hal-hal yang erat kaitannya dengan Relasi dan Fungsi serta kondisi di lapangan.

Sumber data dalam penelitian ini adalah siswa kelas VIII SMP Negeri 11 Kota Bima. Keseluruhan siswa tersebut merupakan subjek angket gaya belajar serta subjek tes kemampuan berpikir kritis pemecahan masalah. Tetapi, hanya 3 siswa yang menjadi subjek penelitian yang diambil dari masing-masing tipe gaya belajar berdasarkan dari hasil jawaban dan merupakan subjek wawancara. Subjek penelitian merupakan informan untuk mendapatkan siswa dengan kemampuan berpikir kritis dalam pemecahan masalah matematika berdasarkan gaya belajar. Penelitian ini hanya dilaksankan pada satu kelas yaitu kelas VIII C.

\section{Instrumen Penelitian.}

Lembar tes berpikir digunakan adalah sejumlah soal essay materi relasi dan fungsi.tes tersebut diberikan kepada subjek penelitian untuk mengetahui siswa yang memiliki kemampuan berpikir kritis pada soal materi relasi dan fungsi. Tes kemampuan berpikir kritis dibuat langsung oleh peneliti dengan memperhatikan siswa yang berpikir kritis dan melakukan validitas terkait kelayakan instrumen dalam penelitian sehingga mengarah pada ketercapaian tujuan yang diinginkan oleh peneliti.

\section{Teknik Analisis Data}

Analisis data dilakaukan dengan tahapan 1) reduksi Data (Data Reduction); 2) Penyajian Data (Data Display); dan 3) Pengambilan kesimpulan. Reduksi data akan memberikan gambaran yang jelas dan mempermudah melakukan pengumpulan data selanjutnya. Reduksi data dalam penelitian ini akan memfokuskan pada siswa yang hasil jawabannya mengacu pada kriteria pemecahan masalah. Kemudian penyajian data adalah proses pengorganisasian data hasil reduksi dalam pola hubungan yang

@ 2021 DIKSI (https://jurnal.bimaberilmu.com/index.php/diksi) 
dapat dipahami. Dalam penelitian kualitatif, penyajian data bisa dilakukan dalam bentuk uraian singkat, bagan, hubungan antar kategori, flowchart dan sejenisnya. Dalam hal ini untuk menyajikan data dalam penelitian kualitatif adalah dengan teks yang berupa naratif. Penarikan kesimpulan dilakukan untuk menjawab rumusan masalah yang ada serta kesimpulan ini dapat berupa temuan yang belum pernah ada sebelumnya. Temuan ini akan dideskripsikan dan digambarkan agar lebih jelas sekaligus mengaitkan dengan kajian kepustakaan dan hasil penelitian yang relevan dengan penelitian ini.

\section{HASIL DAN PEMBAHASAN}

Data penelitian ini mengarah kepada konsepsi penelitian kualitatif dengan menyebarkan tes, observasi dan wawancara. Data yang utama diperoleh dari analisis hasil tes yang dikerjakan siswa, kemudian dari hasil wawancara, serta dari hasil observasi peneliti. Disini terlihat kesulitan-Berpikir Kritis Siswa terdiri dari kesulitan memahami maksud soal, kesulitan dalam merumuskan rencana penyelesaian, menjalankan rencana penyelesaian dan melihat kembali hasil pengerjaan soal.

Dilaksanakan tes di kelas VIII SMP Negeri IIta Bima dalam pokok bahasan Relasi dan Fungsi. Tes diujikan pada siswa kelas $\mathrm{C}$ dengan jumlah siswa 28 orang. Tetapi pada saat tes dilaksanakan hanya 17 orang siswa yang hadir. Pada umumnya dari keseluruhan soal, proporsi siswa yang menjawab benar semua pada soal masih tergolong rendah. Pada butir soal nomor 2 terdapat 0 siswa yang dapat menjawab benar atau keseluruhan siswa mengalami hambatan dalam menjawab soal. Pada butir soal nomor 3 terdapat 11 siswa yang dapat menjawab soal dengan benar, itu berarti ada 6 siswa yang mengalami hambatan dalam menjawab soal. Pada butir soal nomor 4 terdapat 4 siswa yang dapat menjawab soal dengan benar, itu berarti ada 13 siswa yang mengalami hambatan dalam menjawab soal. Pada butir soal nomor 5 terdapat 5 siswa yang mampu menjawab soal dengan benar, itu berarti ada 4 siswa yang mengalami hambatan dalam menyelesaikan soal cerita dan sebagian ada yang tidak menjawab.

Berdasarkan hasil tes yang telah dianalisis oleh peneliti menggunakan pemecahan masalah, masih banyak siswa yang mengalami kesulitan memahami masalah yang telah di berikan. Hanya beberapa siswa saja yang mampu memahami dan merumuskan rencana penyelesaian pada soal nomor 1, 5 siswa yang mengalami kesulitan dalam menjalankan rencana penyelesaian, dan hanya 2 orang yang melihat kembali hasil penyelesaiannya.

Berikut adalah Berpikir Kritis Siswa dalam menyelesaikan soal nomor 1:

@ 2021 DIKSI (https://jurnal.bimaberilmu.com/index.php/diksi) 


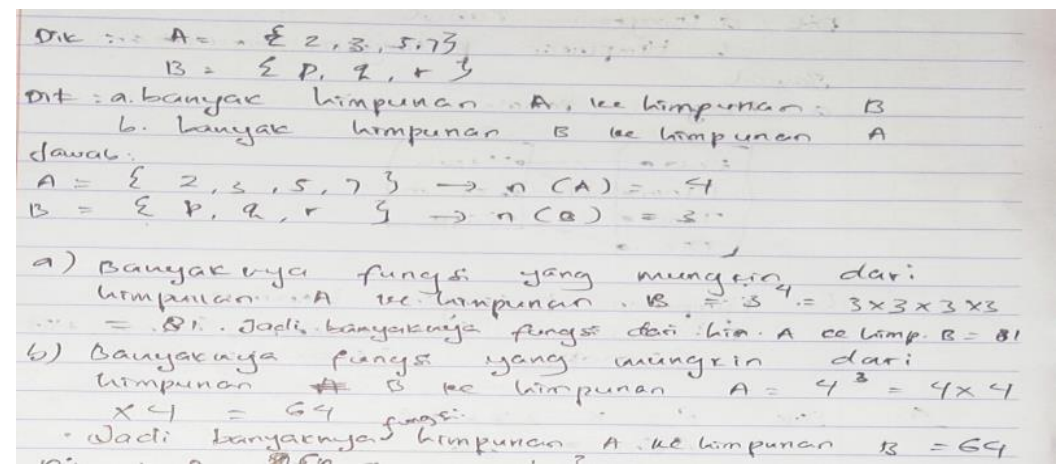

Gambar 1. Proses Berpikir Kritis dalam memecahkan masalah soal nomor 1 pada siswa A

Berdasarkan proses berpikir kritis dalam memecahkan masalah, pada Gambar 1 siswa A sudah mampu memahami soal dengan baik, terlihat bahwa siswa mampu merumuskan rencana penyelesaian dan menjalankan rencana penyelesaian dengan benar sehingga mendapatkan hasil jawaban yang benar juga. Hal ini sesuai dengan yang diharapkan oleh peneliti. Sehingga berpikir kritis siswa tergolong tinggi dalam menyelesaikan soal.

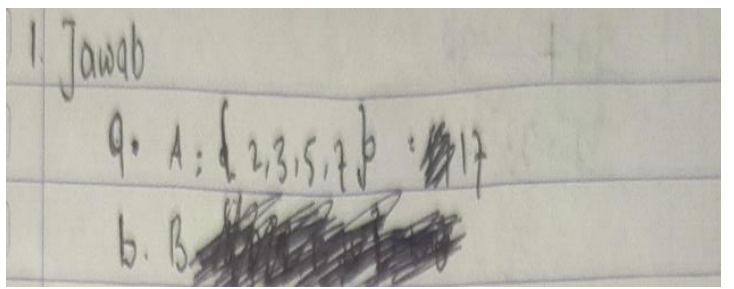

Gambar 2. Berpikir kritis dalam Memecahkan Masalah pada Soal nomor 1 oleh siswa B.

Dalam Gambar 2 terlihat cara berpikir kritis siswa rendah dalam merumuskan rencana penyelesaian yang diberikan pada soal nomor 1, siswa tidak mampu membuat apa yang diketahui dan apa yang ditanyakan dalam soal. Artinya, siswa kurang paham pada masalah yang disajikan dalam soal karena siswa tidak memahami soal dengan baik.

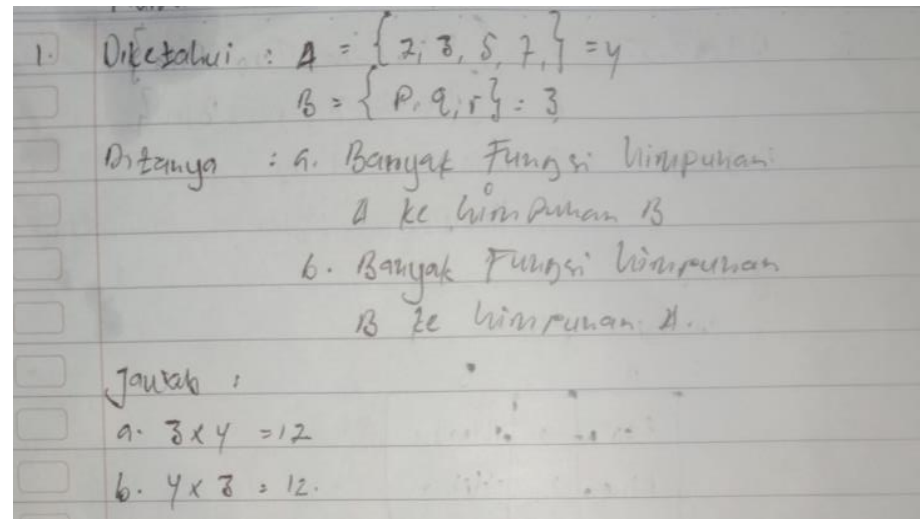

Gambar 3. Berpikir kritis siswa dalam Menjalankan Rencana Penyelesaian pada Soal Nomor 1 oleh siswa C.

@ 2021 DIKSI (https://jurnal.bimaberilmu.com/index.php/diksi) 6

Ciptaan disebarluaskan di bawah Lisensi Creative Commons Atribusi 4.0 Internasional

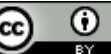


Berdasarkan pemecahan masalah, berpikir kritis siswa dalam menjalankan rencana penyelesaian pada soal nomor 1 , terlihat dari pengerjaan soal siswa $\mathrm{C}$ sudah mampu memahami soal dengan baik dan sudah merumuskan penyelesaian dengan tepat dan menulis apa permasalahan pada soal tetapi salah dalam menjalankan rencana penyelesaian pada soal. Siswa merasa berpikir kritis siswa menjalankan rencana penyelesaian kurang atau sedang karena siswa sudah mampu merumuskan rencana penyelesaian dengan baik tetapi salah dalam menjalankan rencana penyelesaian soal.

Dari penjelasan diatas diperkuat oleh hasil penelitian relevan yang dilakukan oleh Kushendri \& Zantthy (2019) memberi penjelasan bahwasanya kesalahan siswa dalam menyelesaikan soal kemampuan pemecahan masalah matematis terletak pada proses memilih dan melaksanakan strategis perhitungan serta siswa belum mampu mengolaborasi strategis yang akan dilakukan untuk melaksanakan perhitungan selanjutnya.sehingga dapat dikatakan bahwa kemampuan pemecahan masalah siswa SMA yang diteliti tergolong cukup walaupun mereka mash banyak yang kesulitan mengerjakan soal.

Siswa yang mempunyai tingkat kecemasan ringan kemampuan berpikir kritisnya sangat tinggi, bagi siswa yang memiliki kekhawatiran sedang kemampuan berpikir kritisnya juga sedang, sedangkan siswa yang memiliki kekhawatiran berat kemampuan kritisnya rendah (Putri, 2019). Siswa kemampuan berpikir kritis tinggi dapat memenuhi syarat semua indikator berpikir kritis yang dimanfaatkan untuk penelitian ini yaitu menginterpretasi permasalahan, menganlisis, mengevaluasi, dan mengiferensi. Sedangkan, siswa dengan kemampuan berpikir kritis rendah kurang mampu memenuhi indikator menganlisis, mengevaluasi, serta mengiverensi (Purwati dkk, 2016).

\section{KESIMPULAN}

Penyebab siswa melakukan kesalahan dalam menyelesaikan soal Relasi dan Fungsi yang ditinjau dari komunikasi matematika diantaranya. Siswa kesulitan dalam mengubah soal cerita ke dalam simbol matematika, siswa tidak terbiasa dalam menuliskan apa yang diketahui dan yang ditanyakan, siswa tidak ingat rumus-rumus pada materi Relasi dan Fungsi, kurangnya latihan untuk soal-soal cerita, siswa sering terburu-buru dalam mengerjakan soal dan tidak mengecek ulang jawaban, anggapan siswa bahwa menuliskan apa yang diketahui dan yang ditanyakan tidak terlalu penting bahkan akan menguraningi waktu dalam perhitungan dan hanya beberapa siswa saja yang mampu memberi kesimpulan soal setiap kali menjawab.

Dengan adanya hasil penelitian ini hendaknya dapat dijadikan masukan dan pertimbangan sebagai salah satu bahan alternatif dalam kemajuan semua mata pelajaran terutama pelajaran matematika serta bisa dijadikan acuan untuk lebih meningkatkan kemampuan berpikir kritis, serta Hendaknya kepada peneliti selanjutnya melakukan penelitian yang relevan dengan penelitian ini seperti menganalisa proses berpikir kritis siswa dalam memecahkan masalah relasi dan fungsi yang lain.

@ 2021 DIKSI (https://jurnal.bimaberilmu.com/index.php/diksi) 


\section{DAFTAR PUSTAKA}

Aunurrahman, (2012), Belajar dan Pembelajaran, Bandung:Alfabeta.

Basri, H., Purwanto, P., As'ari, A. R., \& Sisworo, S. (2019). Investigating Critical Thinking Skill of Junior High School in Solving Mathematical Problem. International Journal of Instruction, 12(3), 745-758. https://doi.org/10.29333/iji.2019.12345a

Facione, P. A. (2011). Critical thinking: What it is and why it counts. Milbrae: California Academic Press

Gunawan, (2013). Metode penelitian kualitatif. Teori dan Praktik. Jakarta: PT BUMI Aksara.

Kushendri \& Zantthy, L,. S. (2019). Analisis Kemampuan Pemecahan Masalah Matematika Siswa SMA.

Purwati, R., Hobri, H., \& Fatahillah, A. (2016). Analisis kemampuan berpikir kritis siswa dalam menyelesaikan masalah persamaan kuadrat pada pembelajaranmodel creative problem solving. KadikmA, 7(1), 84-93.

Putri, (2019). Meningkatkan kemampuan berpikir kritis dalam mata pelajaran IPS terpadu dengan menggunakan model pembelajaran TGT dengan media video scribe pada siswa SMPN 19 Kota Jambi, STKIP PGRI Sumatera Barat.

Rachmantika, A. R., \& Wardono, W. (2019). Peran Kemampuan Berpikir Kritis Siswa pada Pembelajaran Matematika dengan Pemecahan Masalah. In PRISMA, Prosiding Seminar Nasional Matematika (Vol. 2, pp. 439-443).

Siswono,T.,Y.,E.(2008). Model Pembelajaran Matematika Berbasis Pengajuan Masalah dan Pemecahan Masalah untuk Meningkatkan Kemampuan Berpikir Kreatif. Surabaya: Unesa University Press.

Sugiyono, (2009). Metode Penelitian Kuantitatif Kualitatif dan R\&B. Bandung: Alfabeta.

Sugiyono, (2012). Metode Penelitian Kuantitatif Kualitatif dan $R \& B$. Bandung: Alfabeta. 